\title{
Expression of Neuronal Acetylcholine Receptor Genes in Vertebrate Skeletal Muscle during Development
}

\author{
Roderick A. Corriveau, Suzanne J. Romano, William G. Conroy, Leticia Oliva, and Darwin K. Berg \\ Department of Biology, University of California at San Diego, La Jolla, California 92093-0357
}

Of the 15 nicotinic ACh receptor genes identified in vertebrates, only four $(\alpha 1, \beta 1, \gamma$, and $\delta)$ have been shown to be expressed in embryonic skeletal muscle at early times. In mammalian muscle a fifth gene $(\epsilon)$ replaces the $\gamma$ gene in expression at later times. The remaining 10 nicotinic receptor genes identified to date $(\alpha 2-\alpha 8, \beta 2-\beta 4)$ are expressed in the nervous system and are considered neuronal genes. Using RNase protection assays, we show here that four of the neuronal-type genes $(\alpha 4, \alpha 5, \alpha 7$, and $\beta 4)$ are expressed in developing chick skeletal muscle. Two of them ( $\alpha 4$ and $\alpha 7)$ decline substantially in transcript abundance between embryonic days 11 and 17 , as does $\alpha 1$, while the other two ( $\alpha 5$ and $\beta 4$ ) show only moderate decreases over the same time period. At embryonic day 8, $\alpha 7$ transcripts are nearly $20 \%$ as abundant as $\alpha 1$ transcripts. In situ hybridizations confirm the presence of $\alpha 7$ transcripts in muscle cells both in cell culture and in embryonic tissue. No evidence was found for expression of the $\alpha 2, \alpha 3, \alpha 8$, or $\beta 3$ genes in muscle. Immunoprecipitations and immunoblot analysis using subunit-specific monoclonal antibodies reveal $\alpha 7$ protein in muscle, and the amount of protein rises and declines with the amount of $\alpha 7$ mRNA during development. Sucrose gradient analysis demonstrates that the $\alpha 7$ protein is present in muscle as a species of 105 , the size expected for a nicotinic receptor. The $\alpha 7$ species in muscle binds $\alpha$-bungarotoxin but does not contain $\alpha 1$ subunits, indicating that the two kinds of $\alpha$-type gene products segregate during assembly. The results suggest that neuronal AChRs may play a role in early muscle development.

[Key words: nicotinic receptors, ACh receptors, $\alpha 7$ mRNA, $\alpha 7$ subunits, $\alpha$-bungarotoxin, gene expression, transcription, neuronal, muscle]

Nicotinic acetylcholine receptors (AChRs) in vertebrate skeletal muscle have provided a model for studying how postsynaptic components are synthesized, assembled, and regulated (reviewed by Hall and Sanes, 1993). The receptors are pentameric membrane proteins containing four kinds of subunits and serve as cation-selective, ligand-gated ion channels that mediate fast, excitatory synaptic transmission to the muscle fibers. In em-

Received Mar. 30, 1994; revised Aug. 1, 1994; accepted Aug. 10, 1994.

Grant support was provided by the National Institutes of Health (Grants R01 NS12601 and P01 NS25916) and the California Tobacco Related-Disease Research Program.

Correspondence should be addressed to Darwin K. Berg, Department of Biology, 0357; University of California, San Diego; 9500 Gilman Drive; La Jolla, CA 92093-0357.

Copyright (C) 1995 Society for Neuroscience $0270-6474 / 95 / 151372-12 \$ 05.00 / 0$ bryonic muscle the receptors are distributed throughout the plasma membrane at a relatively low density and are composed of two $\alpha 1$ subunits and one each of $\beta 1, \gamma$, and $\delta$ subunits. After the muscle becomes innervated and muscle activity ensues, several changes occur. Expression of the four AChR genes declines and becomes restricted to muscle nuclei in the vicinity of the neuromuscular junction. AChRs disappear from extrasynaptic regions on the muscle and become highly concentrated in the subsynaptic folds underlying the nerve terminal. Coincident with these changes, in rat and bovine muscle the $\gamma$ gene ceases to be transcribed and in its place transcripts appear from the AChR $\epsilon$ gene. AChRs synthesized at subsequent times contain principally $\epsilon$ instead of $\gamma$ subunits and have different single-channel properties from those of the $\gamma$-containing embryonic receptors.

Gene cloning efforts have identified 10 additional members of the AChR gene family in vertebrates (for review, see Sargent, 1993). Seven have been classified as $\alpha$-type genes $(\alpha 2-\alpha 8)$ because they contain the two vicinal cysteines analogous to those at amino acid positions 191 and 192 in the $\alpha 1$ gene. Three have been designated $\beta$-type genes ( $\beta 2-\beta 4$ ) because they lack the two vicinal cysteines but are very similar in sequence to other members of the family. Expression studies in Xenopus oocytes together with subunit analysis of native receptors have confirmed that a number of the genes do indeed encode subunits of functional AChRs. Each of the 10 genes is expressed in the nervous system and therefore is thought to represent a neuronal AChR gene.

We report here that several neuronal $\mathrm{AChR}$ genes are expressed in embryonic skeletal muscle. One of these, $\alpha 7$, produces transcript levels nearly $20 \%$ as high as $\alpha 1$ during early stages of development. Moreover, the $\alpha 7$ transcripts are translated into protein, and the protein assembles into a putative receptor that binds $\alpha$-bungarotoxin ( $\alpha \mathrm{Bgt})$ and is distinct from conventional muscle AChRs containing $\alpha 1$ subunits. Both $\alpha 7$ transcripts and $\alpha 7$ protcin dccline in amount at late embryonic stages, as do $\alpha 1$ transcripts and protein. The finding of a putative neuronal AChR in embryonic muscle indicates that the tissue-specific division of AChR gene expression is less categorical than previously recognized and raises the possibility that neuronal AChRs participate in muscle development.

\section{Materials and Methods}

$R N A$ probes. ${ }^{32} \mathrm{P}$-labeled riboprobes used for $\mathrm{RNase}$ protection experiments were generated for the chicken $\alpha 2, \alpha 3, \alpha 4, \alpha 5, \alpha 7, \alpha 8, \beta 2, \beta 3$, and $\beta 4$ genes by "runoff transcription" using methods and DNA constructs previously described (Corriveau and Berg, 1993). Similar methods were used to generate $\alpha \mathrm{l}$ riboprobe from linearized $\mathrm{p} \alpha 7$ (Shieh et al., 1987), which contains exon VII of the chicken $\alpha 1$ gene. The sizes (number of bases) of the undigested probes and the corresponding species that would be protected by native transcript are as follows (probe, 
undigested size/protected size): $\alpha 1,408 / 224 ; \alpha 2, \sim 350 / 300 ; \alpha 3,511 /$ $384 ; \alpha 4, \sim 600 / 595 ; \alpha 5,217 / 130 ; \alpha 7,224 / 166 ; \alpha 8,211 / 154 ; \beta 2,235 /$ $216 ; \beta 3,275 / 239 ; \beta 4,414 / 341$.

${ }^{35}$ S-labeled $\alpha 1$ and $\alpha 7$ riboprobes were used for in situ hybridization analysis. Exon 7 of the chicken $\alpha 1$ gene was subcloned from $p \alpha 7$ (Shieh et al., 1987) into pSP72 (Promega) to generate $\alpha$ lpSP72. Sense and antisense ${ }^{35}$ S-labeled probes corresponding to exon 7 were generated using appropriately linearized $\alpha 1 \mathrm{pSP} 72 . \alpha 7$ probes were generated using linearized pCH 34-1; sense probe consisted of 673 bases corresponding to amino acids 179-401, and antisense probe consisted of 684 bascs of $3^{\prime}$ untranslated sequence (Schoepfer et al., 1990). After synthesis probes were separated from unincorporated nucleotides by three consecutive ethanol precipitations, alkaline hydrolyzed, reprecipitated, quantified by scintillation counting, and used at about $5 \times 10^{6} \mathrm{cpm} / \mathrm{ml}$.

RNA isolation. Muscle, brain, ciliary ganglia, and liver were rapidly dissected from chick embryos at the indicated times and immediately frozen in liquid nitrogen. For some experiments RNA was extracted immediately after dissection without freezing in liquid nitrogen. Total RNA was isolated from both dissected tissue and cell cultures by extraction with an acid guanidinium thiocyanate-phenol-chloroform mixture as previously described (Chomczynski and Sacchi, 1987). RNA was quantified by measuring $\mathrm{OD}_{260}$.

RNase protection. RNase protection experiments were carried out as previously described (Corriveau and Berg, 1993). Protected sequences were separated from digested products by ethanol precipitation and electrophoresis in $5 \%$ polyacrylamide gels containing $8 \mathrm{M}$ urea. The gels were dried onto Whatman $3 \mathrm{~mm}$ paper and exposed at $-70^{\circ} \mathrm{C}$ to Kodak XAR-5 x-ray film using a Du Pont Cronex intensifying screen. Signals were quantified directly from the gels using a Molecular Dynamics PhosphorImager. After taking the specific activities of the probes into account and normalizing for the amount of total RNA analyzed, the amounts of neuronal AChR transcripts were compared on a percent basis with the amount $\alpha 1$ transcript present. Control experiments demonstrated that the signals observed were proportional in a linear manner to the amount of transcript present (Fig. 1; Corriveau and Berg, 1993, and unpublished observations).

In situ hybridization. $\alpha 1$ and $\alpha 7$ RNA probes labeled with $\alpha{ }^{-35}$ S-UTP were used to detect hybridizing material in muscle using methods previously described (Simmons et al., 1989) with minor modifications. Briefly, muscle tissue was fixed in $4 \%$ paraformaldehyde $/ 0.5 \%$ glutaraldehyde and embedded in paraftin. Ten-micrometer-thick sections were cut and mounted on Fisherbrand Superfrost/Plus microscope slides. The tissue sections were dewaxed, hydrated, permeabilized with proteinase K, and dehydrated with ethanol. Myotube cultures were prepared as described below (except they were plated on collagen-coated Fisherbrand Superfrost/Plus microscope slides), fixed in $4 \%$ paraformaldehyde, permeabilized with proteinase $\mathrm{K}$, and dehydrated. Hybridization with labeled RNA probes was carried out for $16-18 \mathrm{hr}$ at $50^{\circ} \mathrm{C}$. Aftcr hybridization the samples were incubated with $20 \mu \mathrm{g} / \mathrm{ml}$ RNase $\mathrm{A}$ and $10 \mathrm{U} / \mathrm{ml}$ RNase $\mathrm{T} 1$ for 30 minutes at $37^{\circ} \mathrm{C}$ to digest the residual probe and then washed in a series of SSC solutions of increasing stringency, ending with $0.1 \times \mathrm{SSC}$ at $68^{\circ} \mathrm{C}$. After exposure to Kodak XAR-5 $\mathrm{x}$-ray film at room temperature, sections were coated with NTB-2 emulsion, exposed for 4 weeks, developed, and stained with hematoxylin and eosin using standard methods (Humason, 1979). Results were analyzed using a light microscope with bright-field and phase-contrast optics.

Solid phase immunoprecipitation. AChRs in embryonic day 11 (E11) chick muscle were solubilized using 2\% Triton X-100 in PBS containing the following protease inhibitors: $1 \mathrm{~mm}$ iodoacetamide, $5 \mathrm{~mm}$ benzamidine, $5 \mathrm{~mm}$ EDTA, $5 \mathrm{~mm}$ EGTA, $0.5 \mathrm{~mm}$ phenylmethylsulfonyl fluoride, and $10 \mu \mathrm{g} / \mathrm{ml}$ soybean trypsin inhibitor. After a $2 \mathrm{hr}$ incubation at $4^{\circ} \mathrm{C}$, insolublc matcrial was removed by centrifugation at $40,000 \times$ $g$. Extracts were recovered and diluted to a concentration of $0.25 \mathrm{gm}$ (wet weight) muscle per milliliter.

AChRs in the muscle extracts were quantified using a solid phase immunoprecipitation assay in which anti-AChR monoclonal antibodies (mAbs) tethered to Immulon 2 Removawells (Dynatech Laboratories, Inc.) were used to bind $\mathrm{AChRs}$ followed by incubation with ${ }^{125} \mathbf{I}-\alpha \mathrm{Bgt}$ or ${ }^{125} I-\mathrm{mAb} 35$ to quantify the number of receptors retained. For the assays, wells were first coated on a shaker overnight at $4^{\circ} \mathrm{C}$ with affinitypurified rabbit anti-rat or rabbit anti-mouse antibodies (Jackson Inc.) at a concentration of $20 \mu \mathrm{g} / \mathrm{ml}$ in phosphate-buffered saline (PBS; 0.15 M sodium chloride plus 0.01 M sodium phosphate, $\mathrm{pH}$ 7.4) containing $0.02 \%$ azide (PBS-azide). The wells were then washed three times with
PBS containing $0.5 \%$ Triton X-100 (PBS-Triton) and incubated on a shaker overnight at $4^{\circ} \mathrm{C}$ with $50 \mu \mathrm{l}$ of anti-AChK antibody diluted in PBS-azide. For $\alpha 7$-containing receptors, $\mathrm{mAbs} 318$ and 319 were used together for immunoprecipitation. The two mAbs recognize different epitopes and have previously been shown to be specific for the $\alpha 7$ gene product (Schoepfer et al., 1990; Vernallis et al., 1993). mAb 319 was used as a hybridoma culture supernatant while mAb 318 was used at a $1: 4^{r}$ ) dilution from a concentrated stock (Schoepfer et al., 1990). To immunoprecipitate $\alpha$ l-containing AChRs, wells were incubated with $\mathrm{m} \Lambda \mathrm{b} 35$ at a concentration of $0.145 \mathrm{~mm}(544 \mu \mathrm{g} / \mathrm{ml})$. To immunoprecipitate AChRs containing $\alpha 4$ or $\beta 4$ subunits, mAbs 289 and B4-1 were used, respectively, at 1:400 dilutions from concentrated stocks. The specificities of mAbs 35,289, and B4-1 in immunoprecipitations have been documented previously (Schoepfer et al., 1990; Conroy et al., 1992; Vernallis et al., 1993).

After loading with the indicated mAbs, the wells were rinsed three times with PBS-Triton and incubated $30 \mathrm{~min}$ at $37^{\circ} \mathrm{C}$ with $3 \%(\mathrm{w} / \mathrm{v})$ nonfat dry milk (Carnation Natural Nonfat Dry Milk) in PBS containing $0.1 \%$ Tween-20 as a blocking step. After an additional three rinses with PBS-Triton, muscle extracts $(25-50 \mu l)$ were added to the wells and incubated overnight at $4^{\circ} \mathrm{C}$ on a shaker. The extracts were removed, and the wells were washed three times with PBS-Triton. Normal rat serum plus normal mouse serum at $2 \%(\mathrm{v} / \mathrm{v})$ each in PBS-Triton were incubated in the wells for $30 \mathrm{~min}$ at $37^{\circ} \mathrm{C}$ followed by incubation with either $10 \mathrm{nM}^{125} \mathrm{I}-\alpha$ Bgt in PBS-Triton plus $10 \mathrm{mg} / \mathrm{ml} \mathrm{BSA}$ or $5 \mathrm{nM}^{125} \mathrm{I}-$ mAb 35 in $2 \%(\mathrm{v} / \mathrm{v})$ normal rat plus normal mouse serum solution for $2 \mathrm{hr}$ at $37^{\circ} \mathrm{C}$. Unbound probe was removed by four washes with PBSTriton, and bound radioactivity was determined by gamma counting individual wells. Nonspecific binding was routinely determined by competing the radiolabeled $\alpha$ Bgt or mAb 35 with an excess of unlabeled $\alpha \operatorname{Bgt}(1 \mu \mathrm{M})$ or mAb $35(500 \mathrm{nM})$, respectively. Net specific binding was calculated by subtracting the nonspecific binding from the binding found in the absence of unlabeled probe. Wells in which the anti-AChR mAb was omitted did not bind ${ }^{125} \mathrm{I}-\alpha \mathrm{Bgt}$ or ${ }^{125} \mathrm{I}-\mathrm{mAb} 35$ specifically. The concentration of ${ }^{125} \mathrm{I}-\alpha \mathrm{Bgt}$ used in the assays was near-saturating for the binding sites examined (data not shown).

Immunopurification. Detergent extracts of E1 1 chick pectoral muscle were prepared as described above to solubilize $A C h R s$, and aliquots of the extracts were incubated with $0.2 \mathrm{ml}$ of Protein G-Sepharose (negative control) or $0.2 \mathrm{ml}$ of mAb 319-Protein G-Sepharose to adsorb $\alpha 7$-containing AChRs. The mAb 319-Protein G-Sepharose was prepared by cross-linking mAb 319 to Protein G-Sepharose 4B Fast Flow (Pharmacia) using dimethyl-pimelimidate as described by Harlow and Lane (1988). Incubations of extract with the resins were carried out in a $15 \mathrm{ml}$ centrifuge tube for $16 \mathrm{hr}$ at $4^{\circ} \mathrm{C}$ on a shaker. After incubation the resin was washed three times with PBS-Triton, three times with PBS-Triton containing $1 \mathrm{M} \mathrm{NaCl}, 5 \mathrm{~mm}$ EDTA, and $5 \mathrm{~mm}$ EGTA, and two more times with PBS-Triton. Bound material was eluted with two $1 \mathrm{ml}$ aliquots of $0.1 \mathrm{M}$ sodium citrate $(\mathrm{pH} 3)$ and then immediately neutralized by adding $1 \mathrm{~m}$ Tris $(\mathrm{pH} 8)$. Eluates were concentrated by ultrafiltration (Centricon-30, Amicon) to $50 \mu$, and aliquots were transferred to clcetrophoresis sample buffer for SDS-P $\Lambda$ GE and immunoblotting as described below.

Immunoblot analysis. AChRs immunopurified from E11 pectoral muscle were analyzed on immunoblots by solubilizing the material in SDS sample buffer containing $5 \% \beta$-mercaptoethanol, subjecting the material to SDS-PAGE on a $9 \%$ polyacrylamide gel, and electroblotting the separated components onto nitrocellulose as previously described (Towbin et al., 1979). The blots were blocked with $3 \%(w / v)$ nonfat dry milk in PBS containing $0.1 \%$ Tween-20, incubated with mAbs for 14 $\mathrm{hr}$ at $4^{\circ} \mathrm{C}$ diluted in the same solution, washed in PBS, $0.05 \%$ Tween20 , and incubated for $2 \mathrm{hr}$ at room temperature with horseradish peroxidase coupled to goat anti-rat IgG (Jackson Laboratories, Inc.) to detect bound mAbs. Signals were visualized by enhanced chemiluminescence (Amersham). Prestained molecular weight markers (Bio-Rad, low range) and thcir cstimatcd molecular weights ( $\mathrm{kDa}$ ) were, for phosphorylase B, 106; bovine serum albumin, 80; ovalbumin, 49.5 ; carbonic anhydrase, 32.5 ; and soybean trypsin inhibitor, 27.5.

Sucrose gradient analysis. Velocity sedimentation analysis of $\alpha \mathrm{Bgt}$ binding components in muscle extracts was performed by layering 0.40 $\mathrm{ml}$ aliquots of $\mathrm{E} 11$ pectoral muscle extract onto $11 \mathrm{ml}$ linear sucrose gradients (5-20\% sucrose in PBS-Triton) and centrifuging for $17 \mathrm{hr}$ in an SW41 Ti rotor (Beckman) at 41,000 rpm at $4^{\circ} \mathrm{C}$. After collecting 1726 fractions from the gradient, the $\alpha$ Bgt-binding species present were quantified either with solid phase assays for $\alpha 1$-containing species (see 

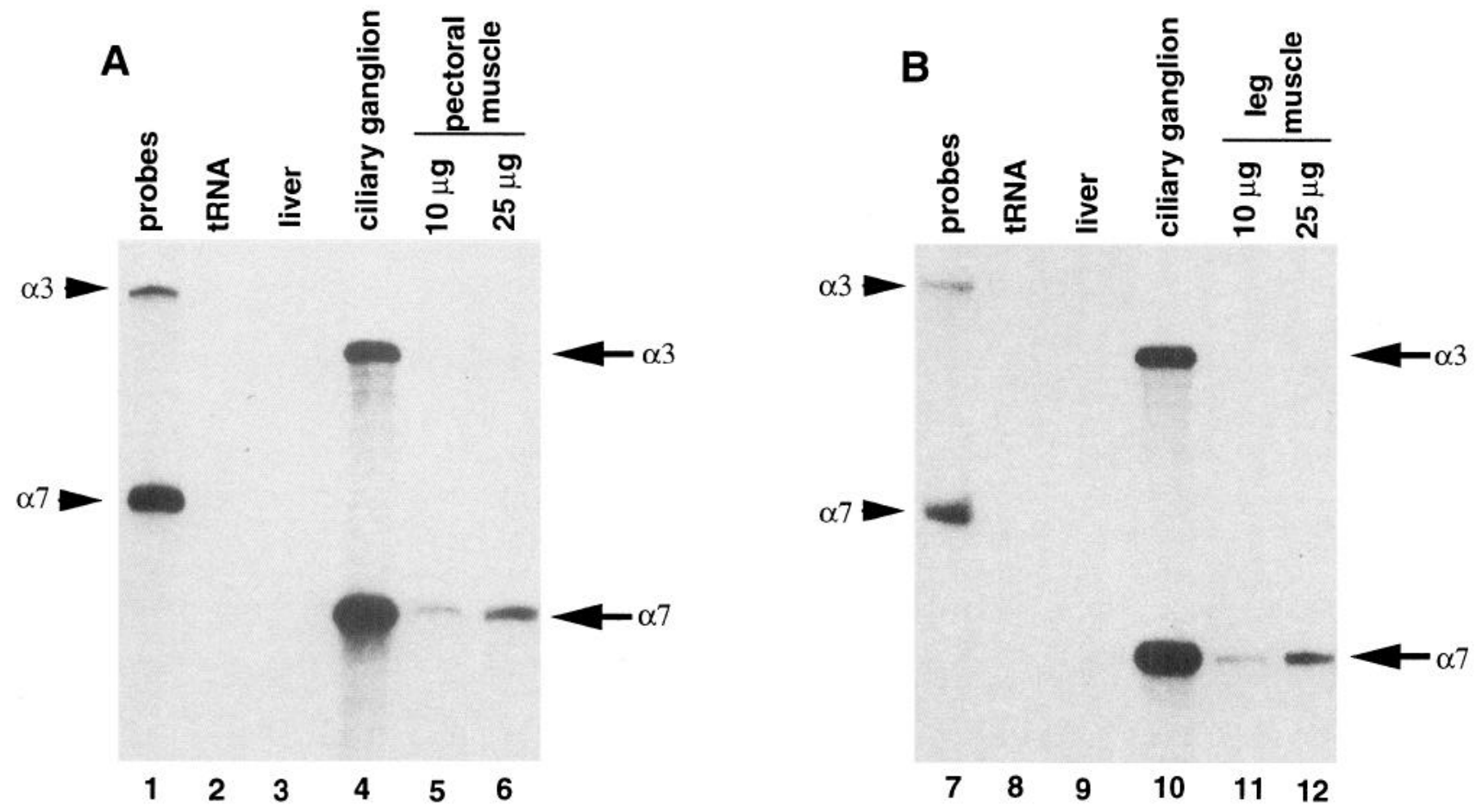

Figure 1. Embryonic pectoral $(A)$ and leg $(B)$ muscles express the $\alpha 7$ gene. RNase protection experiments were carried out with ${ }^{32} \mathrm{P}$-labeled $\alpha 3$ and $\alpha 7$ antisense probes (lanes 1 and 7) using $10 \mu \mathrm{g}$ of tRNA (lanes 2 and 8), $25 \mu \mathrm{g}$ of E17 liver RNA (lanes 3 and 9), $5 \mu \mathrm{g}$ of E15 ciliary ganglion RNA (lanes 4 and 10), and the indicated amounts of RNA isolated from E8 pectoral (lanes 5 and 6) and E11 leg muscle (lanes 11 and 12). Liver RNA and tRNA served as negative controls, and ciliary ganglion RNA as a positive control in each experiment. $\alpha 7$ transcripts are present in RNA extracted from both types of muscle, while $\alpha 3$ transcripts are present in neither. The expected shifts in size occur between the full-length probes (arrowheads) and the protected species (arrows). Similar results were obtained in eight additional experiments with pectoral muscle and one with leg muscle.

above) using $0.035-0.045 \mathrm{ml}$ per fraction or with modified immunoprecipitation binding assays for $\alpha 7$-containing species using $0.4-0.5 \mathrm{ml}$ per fraction. For the modified assays, $\mathrm{mAbs} 318$ and 319 were adsorbed to Protein G-Sepharose and washed with PBS-Triton to remove excess antibody. The adsorbed antibodies were incubated overnight at $4{ }^{\circ} \mathrm{C}$ with the fraction aliquots, washed twice with $1 \mathrm{ml}$ of PBS-Triton, and then incubated with $10 \mathrm{nM}{ }^{125} \mathrm{I}-\alpha \mathrm{Bgt}$ for $2 \mathrm{hr}$ with shaking at room temperature, washed four times, and counted for gamma radiation. Nonspecific binding was determined either by omitting the gradient fraction or by including $1 \mathrm{~mm}$ nicotine in the incubation with ${ }^{125} \mathrm{I}-\alpha \mathrm{Bgt}$; the values were subtracted from the total to obtain specific binding. Recoveries ranged from $25 \%$ to $90 \%$ among experiments for the two $\alpha$ Bgt-binding species.

Cell cultures. Myotube cultures were prepared from E11 chick pectoral muscle essentially as previously described (Fischbach, 1972). Briefly, the muscle tissue was minced with forceps, incubated at $37^{\circ} \mathrm{C}$ for 30 min in a divalent cation-free salt solution to promote cell dissociation, triturated to disperse cells, filtered twice through a Millipore Swinnex13 filter to remove tissue fragments, and incubated $15 \mathrm{~min}$ at $37^{\circ} \mathrm{C}$ on plastic $60 \mathrm{~mm}$ culture dishes to remove fibroblast-like cells, which preferentially adhere to the plastic. The cell suspension (about $2 \times 10^{6}$ cells in $4 \mathrm{ml}$ ) was then plated on collagen-coated $60 \mathrm{~mm}$ culture dishes (Falcon) in culture medium containing $5 \%(\mathrm{v} / \mathrm{v})$ embryo extract and $10 \%(\mathrm{v} / \mathrm{v})$ heat-inactivated horse serum in Eagles Minimal Essential Medium supplemented with glutamine, glucose, and penicillin/streptomycin (GIBCO-Bethesda Research Labs). After $2 \mathrm{~d}$ the medium was replaced with new medium containing $2 \%$ embryo extract and $10^{-5} \mathrm{M}$ cytosine $\beta$-D-arabinofuranoside (ara C) to inhibit proliferating cells. After 2 more days, the medium was again changed, substituting $3 \%(\mathrm{v} / \mathrm{v})$ embryonic eye extract (Nishi and Berg, 1981) for the embryo extract and omitting ara $\mathrm{C}$. The cultures were then maintained in the medium for up to $7 \mathrm{~d}$ with feeding (replacing $50 \%$ of the medium) at $2-3 \mathrm{~d}$ intervals.

Materials. White Leghorn embryonated chick eggs were obtained locally and maintained at $39^{\circ} \mathrm{C}$ in a humidified incubator as described
(Boyd et al., 1991). mAb 35 was purified and radioiodinated as previously described (Smith et al., 1985). $\alpha$ Bgt was purified from Bungarus multicinctus venom (Ravdin and Berg, 1979) and radioiodinated to a specific activity of $0.5-0.7 \times 10^{18} \mathrm{cpm} / \mathrm{mol}$ using chloramine T. Tissue extracts and culture media were prepared as described previously (Nishi and Berg, 1981). p $\alpha 7$, which contains exon VII of the $\alpha 1$ gene, was a generous gift of Dr. Jakob Schmidt (Shieh et al., 1987). Other compounds were obtained from Sigma unless otherwise indicated.

\section{Results}

Expression of $A C h R \alpha 7$ gene transcripts in vertebrate muscle. RNase protection experiments demonstrated that the $\alpha 7$ gene is expressed in developing muscle. Total RNA extracted from both embryonic pectoral and leg muscle was hybridized with $\alpha 7$ and $\alpha 3$ antisense probes. The $\alpha 7$ probe was protected, indicating the presence of $\alpha 7$ transcripts in the muscle RNA samples (Fig. 1). The $\alpha 3$ probe was not protected. Total RNA extracted from ciliary ganglia and used as a positive control protected both probes. The likelihood of false positive results for $\alpha 7$ mRNA expression in muscle is remote because of the following considerations. (1) The $\alpha 7$ probe was protected as a single species of the predicted size. (2) No $\alpha 3$ transcripts were detected in muscle. (3) Neither liver RNA nor tRNA protected the $\alpha 7$ probe, indicating that the probe did not interact with itself or nonhomologous sequences in ways that protected a species of the size observed. (4) The chicken $\alpha 7$ probe used in these experiments was not protected by very similar rat $\alpha 7$ mRNA (Corriveau and Berg, 1993). Other AChR mRNA species present in muscle would be less similar and therefore should not protect the $\alpha 7$ probe. 

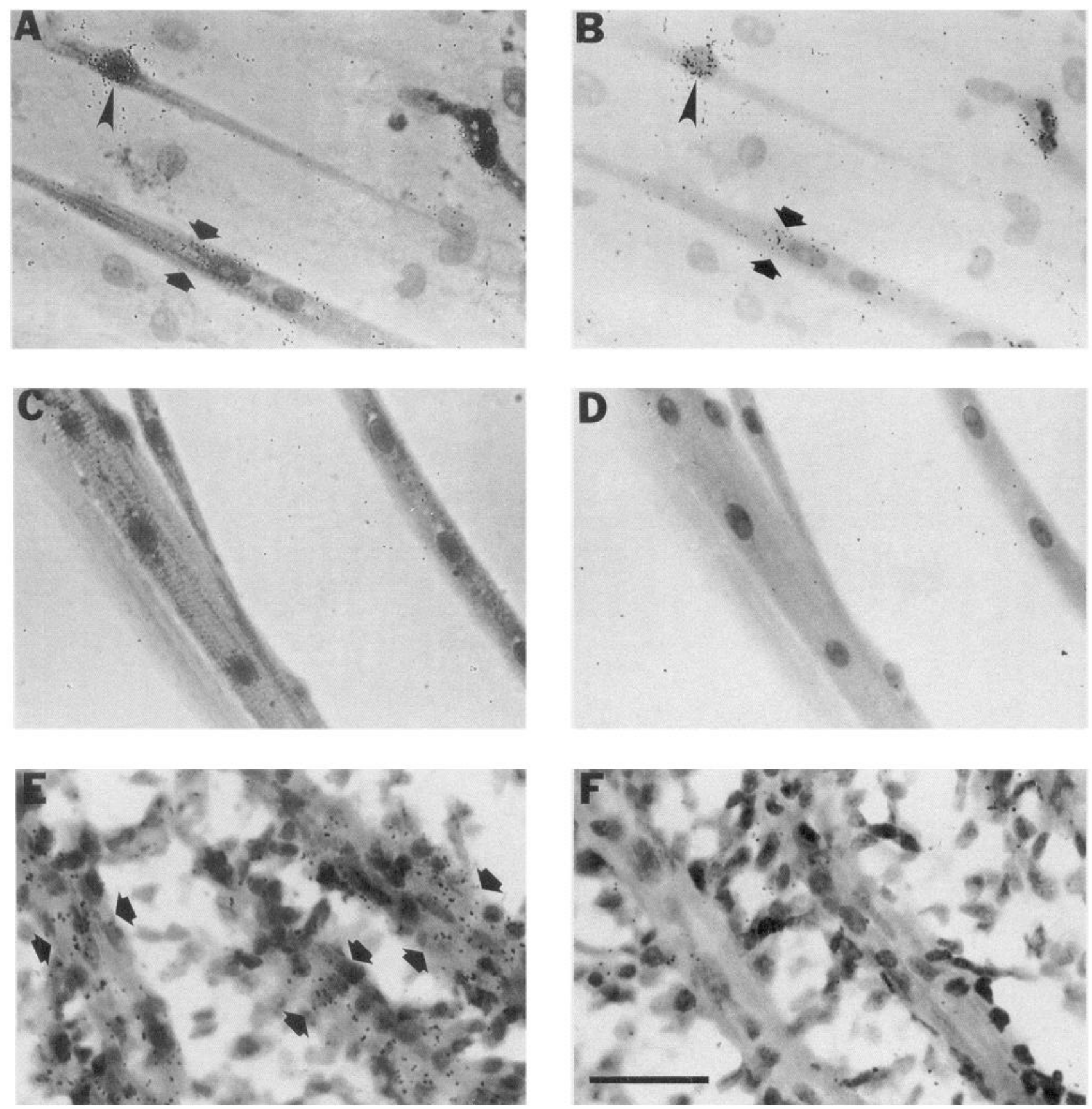

Figure 2. In situ hybridizations demonstrating that the $\alpha 7$ gene is expressed in muscle cells. Cultures of skeletal muscle $(A-D)$ and microtome sections $(10 \mu \mathrm{m})$ of E11 leg muscle $(E, F)$ were hybridized with ${ }^{35}$ S-labeled probe, coated with emulsion, exposed for 4 weeks, developed, and stained with hematoxylin and eosin. For muscle cultures, each horizontal pair of photomicrographs represents the same field of view: phase-contrast optics $(A, C)$ emphasize cell morphology and bright-field optics $(B, D)$ accentuate silver grains. Tissue sections are shown using bright-field optics $(E, F)$, which reveal both cell morphology and silver grains. $\alpha 7$ antisense probe hybridized to myotubes (examples of labeled myotubes are delineated by arrows) both in cell culture $(A, B)$ and in vivo $(E)$. Myocytes present in cell culture were also labeled $(A, B$, arrowheads). Labeling of muscle cells by $\alpha 7$ antisense probe varied from little, if any, to relatively high levels such as is seen over the myocyte depicted in $A$ and $B$. Heterogeneity of $\alpha 7$ expression among nuclei within the same myotube was also evident both in cell culture and in vivo. Hybridization to tissue sections of E11 pectoral muscle produced similar results. Background levels of silver grains were observed over extracellular spaces and cells hybridized with $\alpha 7$ sense probe $(C, D, F)$. Scale bar: $40 \mu \mathrm{m}$ for $A-D, 25 \mu \mathrm{m}$ for $E$ and $F$.

Localization of $\alpha 7$ transcripts within muscle. While the RNase protections clearly demonstrated $\alpha 7 \mathrm{mRNA}$ in dissected embryonic muscle, this tissue typically includes nonmuscle cell types such as fibroblasts and chondroblasts along with myoblasts and myotubes. In addition, the unusual finding of a neuronal AChR mRNA in a non-neuronal tissue raised concerns about neuronal contamination of the samples. Accordingly, it was important to determine whether muscle cells express the $\alpha 7$ gene. For localization, in situ hybridization experiments were initially carried out with muscle cell cultures where myotubes can be readily distinguished. Cultures were prepared with dissociated E11 pectoral muscle and treated with ara $\mathrm{C}$ to depress 


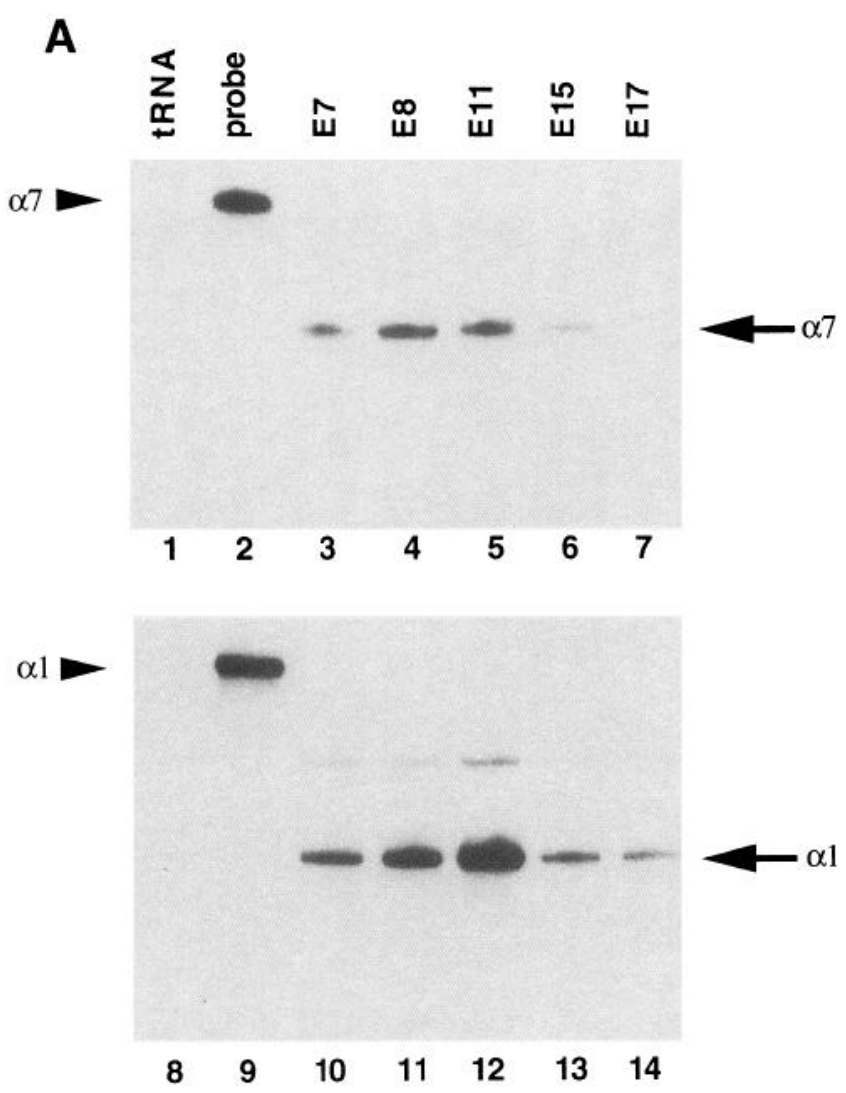

B

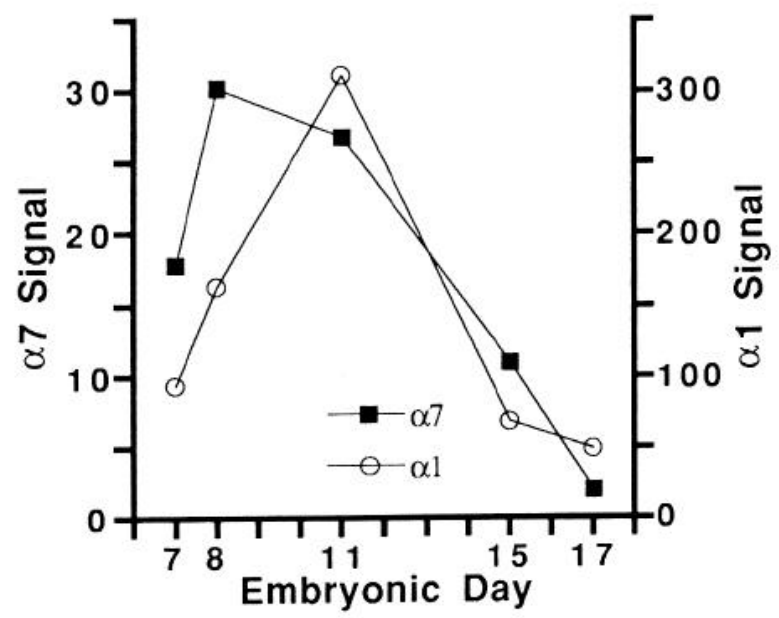

Figure 3. RNase protection experiment comparing the amounts of $\alpha 7$ and $\alpha 1$ transcripts present in developing pectoral muscle at the indicated times. $A,{ }^{32} \mathrm{P}$-labeled $\alpha 7$ and $\alpha 1$ antisense probes (lanes 2 and 9, arrowheads) were protected from RNase digestion with either 15 (upper) or $5 \mu \mathrm{g}$ (lower) of total RNA extracted from pectoral muscle at the indicated stages of development. Protections with equivalent amounts of tRNA were used as negative controls (lanes 1 and 8 ). The amount of radioactivity associated with each protected species (arrow) was measured directly from the gel using a Molecular Dynamics PhosphorImager. $B$, To compare the absolute amounts of $\alpha 7$ and $\alpha 1 \mathrm{mRNAs}$ as well as the patterns of expression during development, signals were corrected for the specific activities of the probes and normalized for the amount of RNA used. The expression patterns for $\alpha 7$ and $\alpha 1$ mRNAs were similar though $\alpha 7$ mRNA levels were 5-10-fold lower than $\alpha 1$ mRNA. Similar results were obtained in two additional experiments. proliferation of dividing cells. Three separate RNase protection experiments demonstrated that $\alpha 7$ mRNA was present in the cultures (data not shown). In situ hybridizations were carried out with ${ }^{35}$ S-labeled $\alpha 7$ riboprobes. The culture slides were dipped in emulsion, exposed, developed to reveal silver grains, and stained using a standard hematoxylin and eosin procedure. The $\alpha 7$ antisense probe specifically labeled multinucleated myotubes as well as occasional myocytes present in the cultures (Fig. $2 A, B$ ). Only background levels of silver grains were observed over cells hybridized with $\alpha 7$ sense probe as a negative control (Fig. 2C,D). Heterogeneity of labeling with antisense probe was evident; not all myotubes or myocytes expressed the $\alpha 7$ gene. Even among nuclei within a myotube, labeling varied from high levels down to background. Similar observations have been made for $\alpha 1$ expression in myotube cultures (Fontaine and Changeux, 1989; R. A. Corriveau, S. J. Romano, and D. K. Berg, unpublished observations).

In situ hybridizations on tissue sections of embryonic skeletal muscle demonstrated that in vivo, as in culture, a subset of myotubes express the $\alpha 7$ gene (Fig. 2E). In addition to myotubes, embryonic muscle tissue includes mononuclear interstitial cells, many of which contain mitotic bodies (Przybylski and Blumberg, 1966). $\alpha 7$ antisense probe specifically labeled a number of interstitial cells (data not shown). While the morphology and location of the cells were consistent with their being myoblasts, definitive identification was not possible with the resolution available. Antisense probe produced only background levels of silver grains over extracellular spaces and cartilage. No evidence was obtained for contaminating neurons, labeled or unlabeled, in the tissue. $\alpha 7$ sense probe produced background labeling over all portions of the sections including myotubes (Fig. $2 F$ ). $\alpha 1$ expression has previously been demonstrated both in myotubes and in myoblasts in vivo (Fontaine and Changeux, 1989); a similar pattern of $\alpha 1$ expression was found in the present experiments (data not shown).

Developmental time course of $\alpha 7$ gene expression. The finding that the $\alpha 7$ gene is expressed in embryonic muscle challenges the traditional division between neuronal and muscle AChR genes and raises questions regarding the abundance, purpose, and regulation of $\alpha 7$ transcripts in muscle. To compare $\alpha 1$ and $\alpha 7$ mRNA expression during muscle development, RNase protection experiments were performed using total RNA extracted from pectoral muscle at E7, E8, E11, E15, and E17 (Fig. 3A). The patterns of expression and the relative abundance of $\alpha 1$ and $\alpha 7$ transcripts were determined by quantifying the signals obtained using a Molecular Dynamics PhosphorImager, taking into account the specific activities of the probes.

$\alpha 7$ mRNA was detected at E7 and reached peak levels per unit total RNA at E8-E11 (Fig. 3). By E17, $\alpha 7$ levels had diminished almost to background. This pattern paralleled that observed for $\alpha 1 \mathrm{mRNA}$, which, as reported previously (Moss et al., 1989), peaked at E11 and decreased about sixfold by E17 (Fig. 3). During the period of peak expression, the $\alpha 7$ transcript was about $15 \%$ as abundant as the $\alpha 1$ transcript.

Muscle expression of other neuronal AChR genes. Of the 10 known neuronal AChR genes, nine were tested for expression in muscle tissue. In addition to $\alpha 7$, these included $\alpha 2, \alpha 3, \alpha 4$, $\alpha 5, \alpha 8, \beta 2, \beta 3$, and $\beta 4$. One gene, $\alpha 6$ (Sargent, 1993), could not be tested because no sequence data were available to permit construction of probes.

RNase protection experiments indicated that both E11 and E17 pectoral muscle contained significant amounts of $\alpha 4, \alpha 5$, 
A

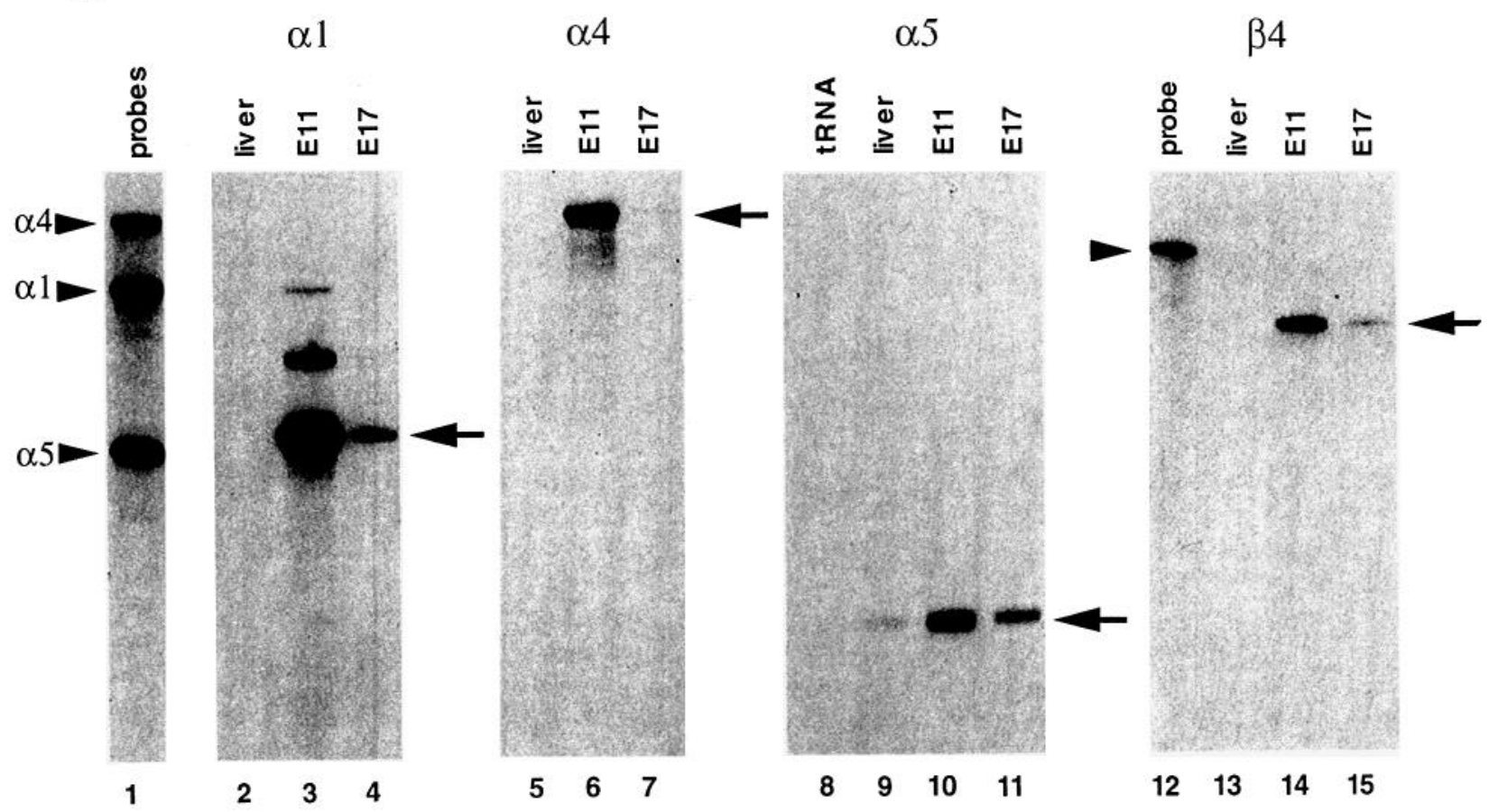

B

$\alpha 2$

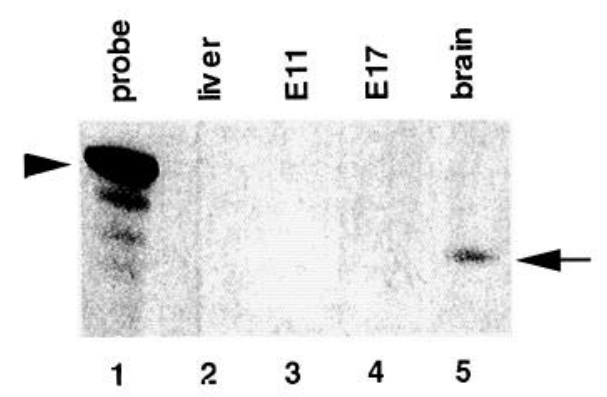

$\alpha 8$

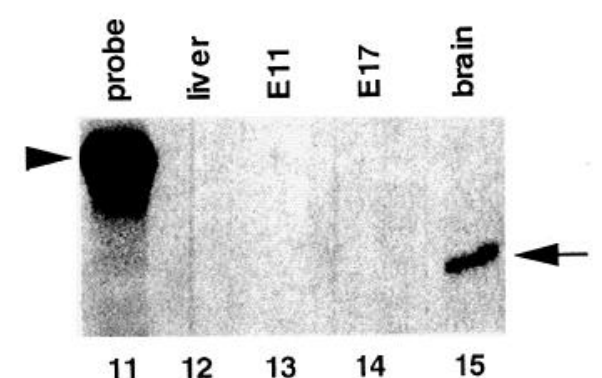

$\alpha 3$

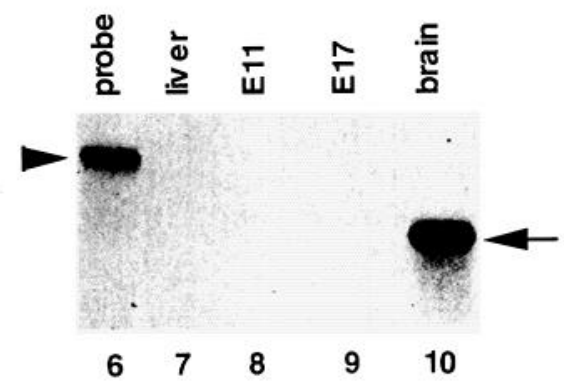

$\beta 3$

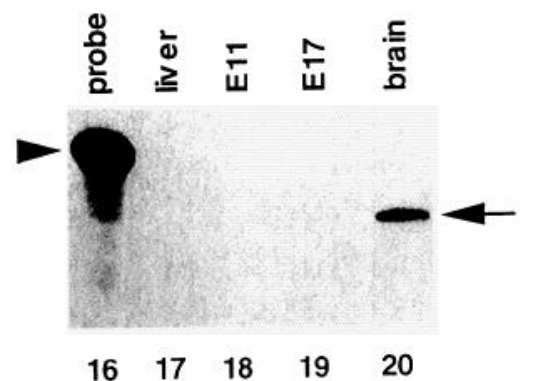

Figure 4. RNase protection experiments demonstrating the presence of additional neuronal AChR transcripts in muscle and the absence of others. $A$, Protection experiments with $\alpha 4, \alpha 5$, and $\beta 4$ probes indicate the presence of the corresponding transcripts in E11 and E17 pectoral muscle. $B$, Protection experiments with $\alpha 2, \alpha 3, \alpha 8$, and $\beta 3$ probes failed to detect transcripts in either E11 or E17 pectoral RNA though positive controls with brain RNA demonstrated that the probes were competent. The experiments were carried out as described in preceding figures with negative control(s) in each case. All hybridizations used $15 \mu \mathrm{g}$ of RNA, and the lanes are labeled to indicate sample composition. Arrowheads indicate the positions of undigested probes and arrows indicate the protected species. Similar results were obtained in two or more additional experiments for each condition. 
A

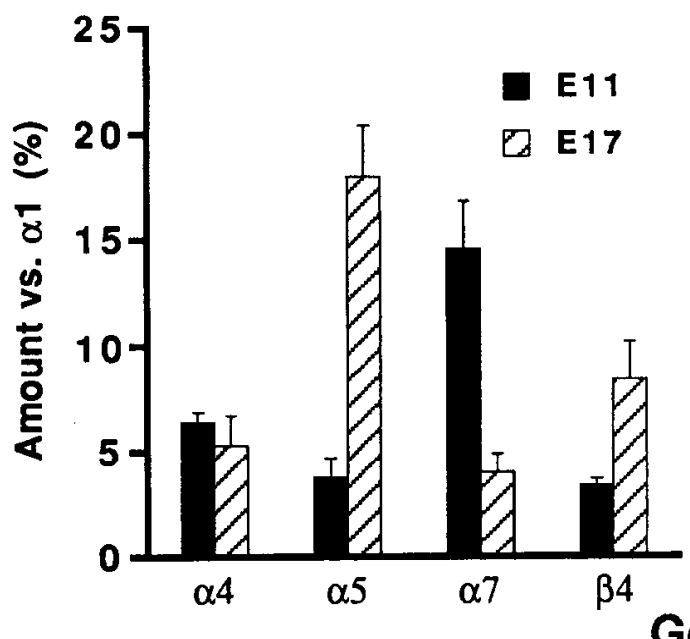

B

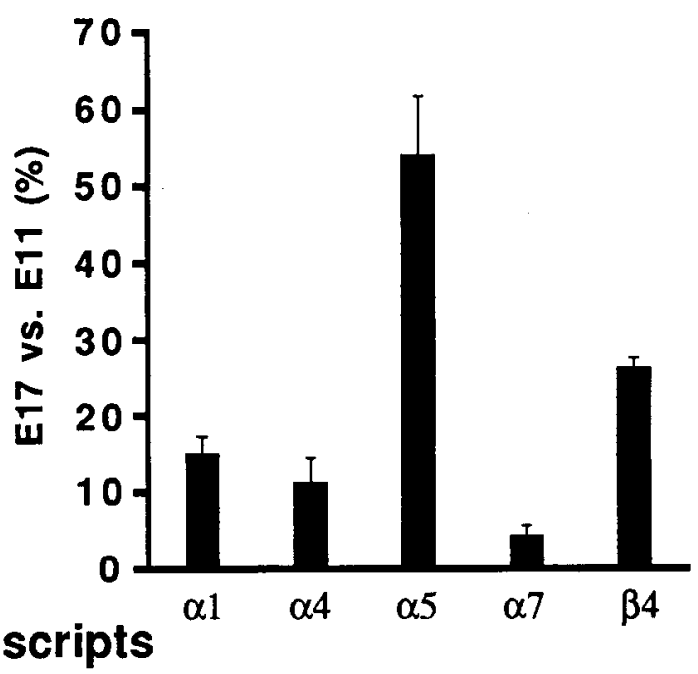

Figure 5. Relative amounts of neuronal AChR transcripts expressed in muscle at two developmental stages. $A$, Comparison of neuronal AChR transcript abundances with $\alpha 1 \mathrm{mRNA}$ levels in E11 and E17 pectoral muscle. $B$, Amount of each AChR transcript present at E17 as a percentage of E11 levels. Experiments were performed as described for Figures 1-4. Signals were quantified directly from dried gels using a Molecular Dynamics PhosphorImager, and corrected for the specific activities of the probes. Values represent the mean \pm SEM of at least three separate experiments in each case.

and $\beta 4$ mRNA (Fig. $4 A$ ). The protections also suggested that $\beta 2$ transcripts were present ( $n=4$; data not shown), but the small amount of $\beta 2$ signal and the high backgrounds obtained (probably due to the high GC content of both the $\beta 2$ coding sequence and the probe) prevented a conclusive determination. No mRNA was detected from $\alpha 2, \alpha 3, \alpha 8$, and $\beta 3$ genes in either E11 or E17 pectoral muscle (Fig. $4 B$ ). The sensitivity of the assay was sufficient to detect transcripts present at levels as low as $1 \%$ of that observed for $\alpha 1$ at E11.

Of the four neuronal AChR genes clearly expressed in em- bryonic muscle ( $\alpha 4, \alpha 5, \alpha 7$, and $\beta 4$ ), only $\alpha 5$ appeared to be expressed at any level in E1 7 liver (Figs. 2, 4). The small amount of $\alpha 5$ protection achieved by liver RNA was specific in that it could not be mimicked by tRNA. The significance of $\alpha 5$ expression at low levels in liver tissue is unclear.

The relative amounts of neuronal AChR gene transcripts in E11 and E17 muscle were quantified using a PhosphorImager as described above and compared to the amounts of $\alpha 1$ transcript. Control experiments demonstrated that the probes, conditions, and levels of RNA used generated signals in RNase

Table 1. Selective immunoprecipitation of putative muscle AChR subtypes with subunit-specific mAbs

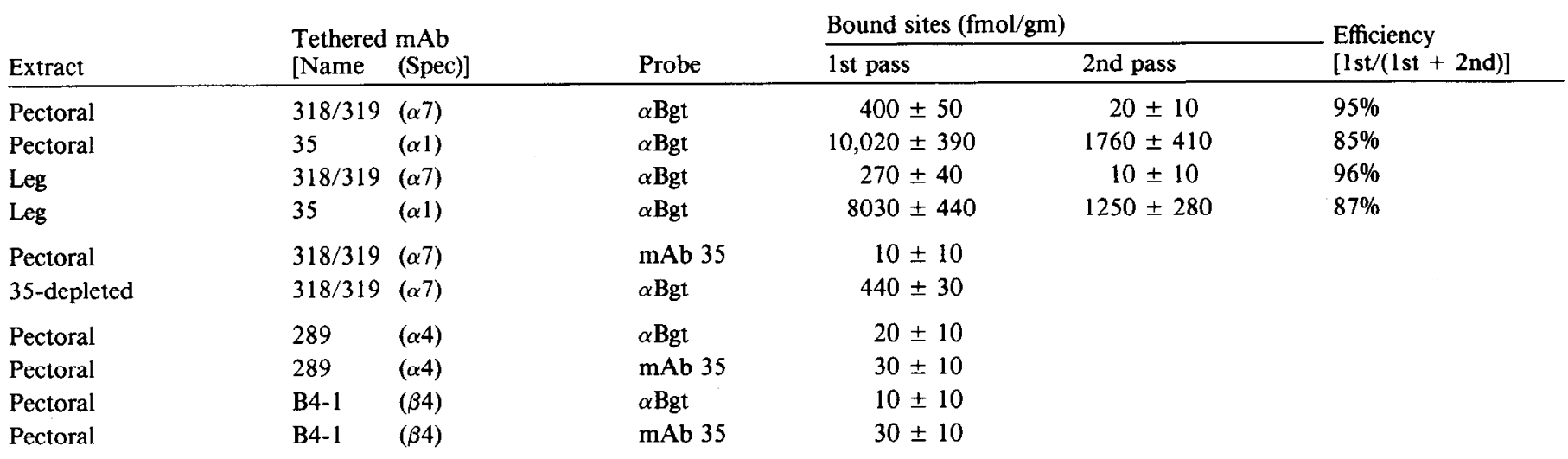

Receptors were retained in the solid phase immunoprecipitation assay by incubating the indicated muscle extract with the specified tethered mAb in a single incubation (1st pass) or, in some cases, after recovering the depleted extract from the first incubation and subjecting it to a second incubation in a new well (2nd pass). Adsorbed receptors were quantified using the indicated radiolabeled probes. The efficiency of the procedure was calculated by determining the proportion of the total receptor (1st +2 2nd pass) that was retained in the 1 st pass. Pectoral, E11 pectoral muscle; leg, E11 leg muscle; 35-depleted, E11 pectoral muscle extract subjected to one round with $\mathrm{mAb} 35$ in a solid phase adsorption prior to the indicated solid phase assay. The subunit specificities of the mAbs for solubilized receptors are as indicated (Spec) except that mAb 35 also immunoprecipitates certain neuronal AChRs (see text). The data represent the mean \pm SEM of at least eight determinations from three or more separate experiments, except for the 2 nd pass results with leg muscle, which represent six determinations from two separate experiments. The results show that putative $\alpha 7$-containing AChRs binding $\alpha$ Bgt are present in both pectoral and leg muscle and are distinct from AChRs containing $\alpha 1$ subunits. Neither class of receptors appears to contain either $\alpha 4$ or $\beta 4$ subunits. mAbs 289 and B4-1 were confirmed as competent by showing in the same experiments that they immunoprecipitated the expected receptor subtypes from chick brain and ciliary ganglia (data not shown). 
protections that were related in a linear manner to the amount of mRNA present in the hybridization (Fig. 1; Corriveau and Berg, 1993, and unpublished observations). Several patterns emerged. The neuronal AChR transcripts were approximately an order of magnitude less abundant in muscle than was the $\alpha 1$ transcript, ranging from $3 \%$ to $18 \%$ depending on the gene and stage of development (Fig. 5A). Both the $\alpha 7$ and $\alpha 4$ transcripts mimicked the $\alpha 1$ transcript in undergoing a sharp decrease in abundance between E11 and E17 (Fig. 5B). The $\alpha 4$ and $\alpha 1$ transcripts decreased almost identical amounts, while $\alpha 7$ declined even further to levels barely detectable in the assay. In contrast, the levels of $\alpha 5$ and $\beta 4$ transcripts decreased only moderately and, as a result, increased in abundance relative to $\alpha \mathrm{l}$ during the same period (Fig. $5 A, B$ ).

Putative AChRs containing $\alpha 7$ protein in muscle. The existence of gene transcripts in a cell does not guarantee the presence of the encoded protein. Recently, the pheochromocytoma cell line PC1 2 has been shown to express high levels of NMDARI mRNA and yet to have only trace amounts of NMDAR 1 protein (Sucher et al., 1993). Accordingly, it was important to determine whether $\alpha 7$ protein could be detected in embryonic muscle. This was done by relying on the fact that $\alpha 7$-containing receptors should bind $\alpha$ Bgt and be immunoprecipitated by mAbs 318 and 319. Previous studies have shown the mAbs to be specific for the $\alpha 7$ gene product both on immunoblots and in immunoprecipitations (Schoepfer et al., 1990; Vernallis et al., 1993).

When detergent extracts of embryonic pectoral muscle were incubated with mAbs $318 / 319$ in solid phase immunoprecipitation assays, significant numbers of $\alpha \mathrm{Bgt}$-binding sites were specifically adsorbed by the antibodies (Table 1 ). The numbers of such sites were far less than the numbers of sites immunoprecipitated by $\mathrm{mAb} 35$, an $\mathrm{mAb}$ known to recognize the chicken $\mathrm{AChR} \alpha \mathrm{l}$ gene product and to bind to receptors containing $\alpha 1$ subunits (Conroy et al., 1992). [mAb 35 also recognizes the $\alpha 5$ gene product on immunoblots and immunoprecipitates receptors containing $\alpha 3 / \alpha 5 / \beta 4$ subunits but such receptors do not bind $\alpha$ Bgt (Vernallis et al., 1993).] The $\alpha$ Bgt-binding components brought down by mAbs $318 / 319$ did not represent a lowaffinity cross-reaction of the mAbs with conventional muscle AChRs $(\alpha 1 / \beta 1 / \gamma / \delta)$. If low-efficiency cross-reactions with conventional muscle $A C h R s$ had been responsible for the immunoprecipitation, significant amounts should also have been obtained in subsequent passes with mAbs 318/319. Instead, immunoprecipitations with mAbs $318 / 319$ were highly efficient in a single pass ( $\geq 95 \%$; Table 1$)$. As a result, it must be concluded that the population of $\alpha$ Bgt-binding sites in muscle extracts immunoprecipitated by mAbs $318 / 319$ is distinct from the large class of $\alpha 1$-containing receptors recognized by $\mathrm{mAb}$ 35. Similar results were obtained from an analysis of embryonic leg muscle extracts (Table 1).

Sucrose gradient analysis was used to determine whether the $\alpha$ Bgt-binding components containing $\alpha 7$ protein had the size expected for AChRs. Extracts prepared from E11 pectoral muscle were fractionated by sedimentation through sucrose gradients, and the fractions were examined for immunoprecipitable $\alpha$ Bgt-binding sites. A prominent species of about $10 \mathrm{~S}$ was obtained for the toxin-binding component recognized by mAbs $318 / 319$ (Fig. 6), a size similar to that reported for neuronal AChRs solubilized from brain and ciliary ganglia (Schneider et al., 1985; Smith et al., 1985; Anand et al., 1993). The major species migrated slightly ahead of the $\alpha 1$-containing AChRs analyzed on the same gradients, confirming the separate identity

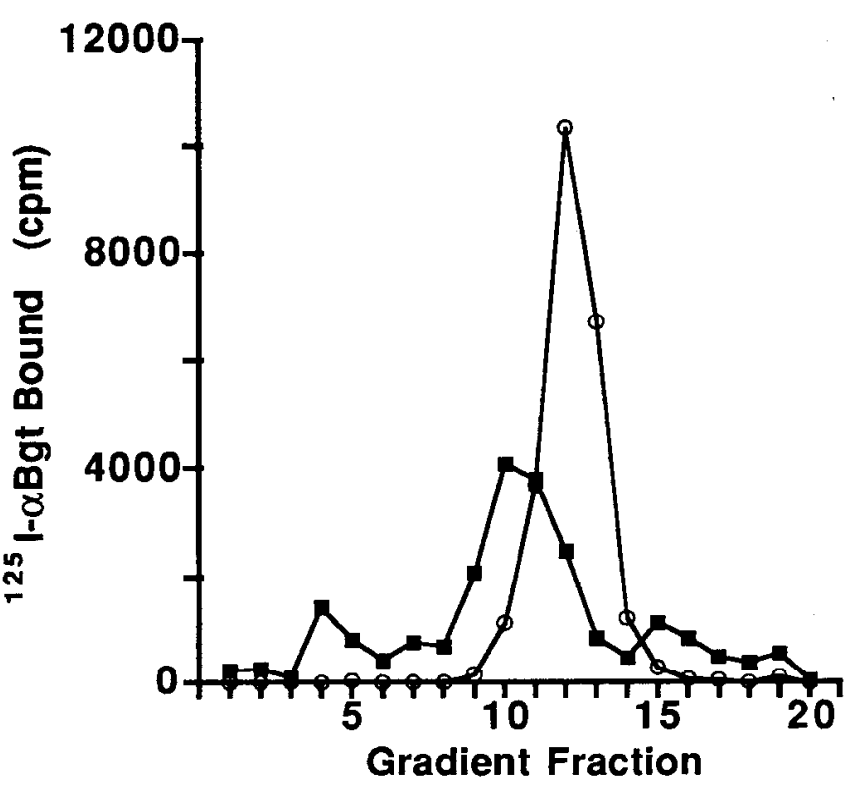

Figure 6. Sucrose gradients showing the size of the $\alpha 7$-containing component that binds $\alpha \mathrm{Bgt}$ in embryonic muscle. Extracts of E11 pectoral muscle were fractionated by sucrose gradient sedimentation, and the fractions were analyzed for $\alpha 7$-containing $(0.4 \mathrm{ml}$ aliquots; solid squares $)$ and $\alpha 1$-containing $(0.05 \mathrm{ml}$ aliquots; open circles $)$ components that bind $\alpha$ Bgt. Sedimentation was from right to left; specific binding is shown from a single gradient. Similar results were obtained in two experiments including a total of four gradients.

of the two classes of components distinguished by immunoprecipitation with mAbs $318 / 319$ and 35 .

Segregation of $\alpha 1$ and $\alpha 7$ gene products into separate muscle components. Expression of the $\alpha 7$ gene in Xenopus oocytes produces receptors that are thought to be homomeric (Couturier et al., 1990; Seguela et al., 1993). In chick brain a portion of the $\alpha 7$ protein is coassembled with $\alpha 8$ subunits to form a subpopulation of native AChRs that bind $\alpha \mathrm{Bgt}$ (Schoepfer et al., 1990). The question of whether $\alpha 7$ subunits are present in muscle AChRs containing $\alpha 1$ subunits was addressed with both immunoprecipitations and immunoblots. In one set of experiments muscle extracts were incubated with mAbs $318 / 319$ to adsorb receptor, and the bound receptor was tested for ${ }^{125} \mathrm{I}-\mathrm{mAb} 35$ binding to determine the amount of $\alpha 1$ protein present. No binding was detected over background (Table 1), suggesting that none of the adsorbed protein contained $\alpha 1$ subunits. A similar conclusion was reached in a second set of experiments in which muscle extracts were first incubated with mAb 35 to deplete $\alpha 1$-containing AChRs. The depleted extracts were then incubated with mAbs $318 / 319$ to determine whether the components recognized by the anti- $\alpha 7 \mathrm{mAbs}$ had been removed. This clearly was not the case (Table 1, "35-depleted"), indicating that the putative AChRs containing $\alpha 7$ subunits did not also contain $\alpha 1$ protein.

The conclusion that the $\alpha 7$ and $\alpha 1$ proteins are segregated into separate muscle components was confirmed by immunoblot analysis. $\alpha 7$-Containing components were partially purified from muscle extracts by using mAb 319 coupled to Protein GSepharose. The bound protein was eluted, submitted to SDSPAGE, and probed on immunoblots with mAbs 318,319, and 210. Since mAbs 318 and 319 recognize distinct epitopes on the $\alpha 7$ subunit (McLane et al., 1992), their ability to detect a species of about $60 \mathrm{kDa}$ in the immunopurified material indi- 


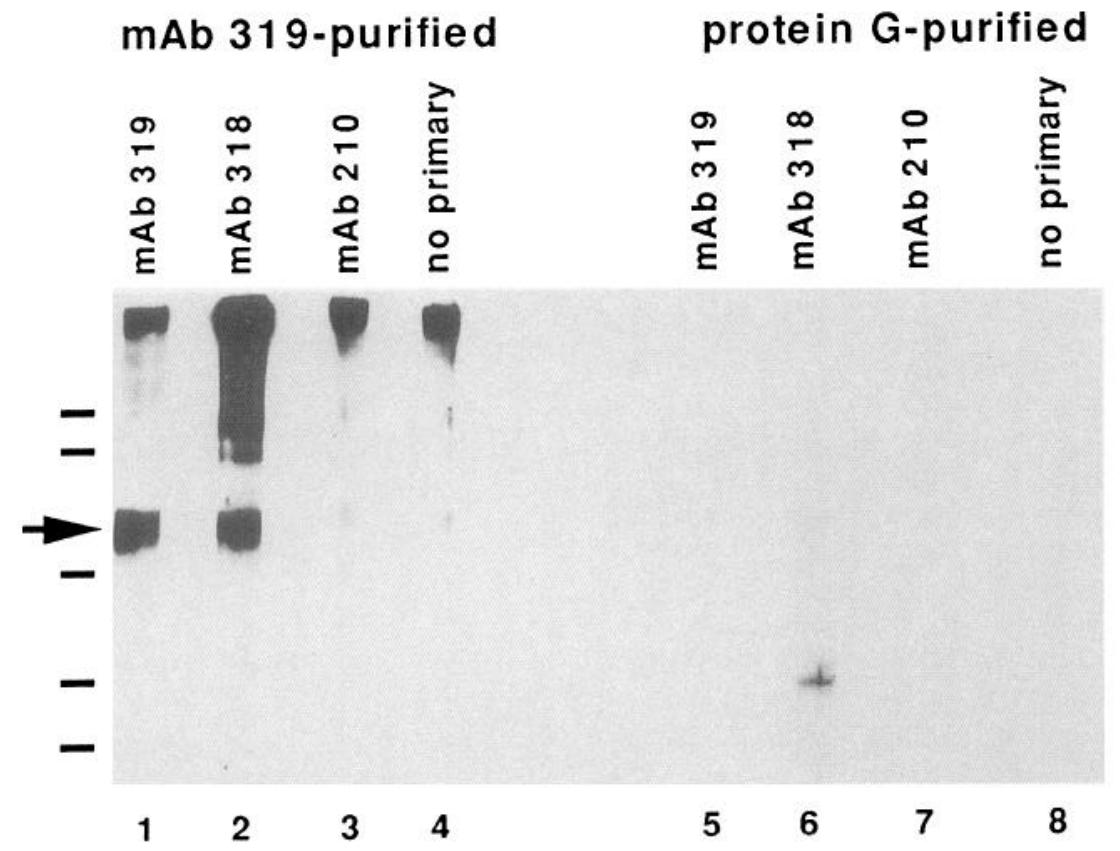

Figure 7. Immunoblots demonstrating the presence of $\alpha 7$ protein in putative AChRs distinct from those containing $\alpha 1$ subunits in muscle. Extracts from E11 pectoral muscle were incubated either with $\mathrm{mAb} 319$-Protein G-Sepharose to immunoprecipitate receptors containing $\alpha 7$ subunits (lanes 1-4) or with Protein G-Sepharose as a negative control (lanes 5-8). The precipitates were then eluted with $0.1 \mathrm{M}$ sodium citrate, pH 3, containing $0.1 \%$ Triton X-100 and analyzed on immunoblots probed with mAbs 319 (lanes 1 and 5) and 318 (lanes 2 and 6), which recognize different epitopes on the $\alpha 7$ protein, mAb 210 (lanes 3 and 7), which recognizes the $\alpha 1$ subunit, and no primary mAb (lanes 4 and 8 ) as a negative control. Bound $\mathrm{mAbs}$ were detected using rabbit anti-rat antibodies coupled to horseradish peroxidase; signals were visualized with enhanced chemiluminescence (Amersham). The size of the immunopurified component identified as $\alpha 7$ (arrow, lanes 1 and 2) is about $60 \mathrm{kDa}$. The material at the top of lanes $1-4$ is most likely cross-linked mAb leached from the resin and recognized by the secondary antibody; some high-molecular-weight material of unknown identity also binds mAb 318 (lane 3). Similar results were obtained in a second experiment. Molecular weight markers (from top to bottom, $\mathrm{kDa}$ ): $106,80,49,32.5,27.5$.

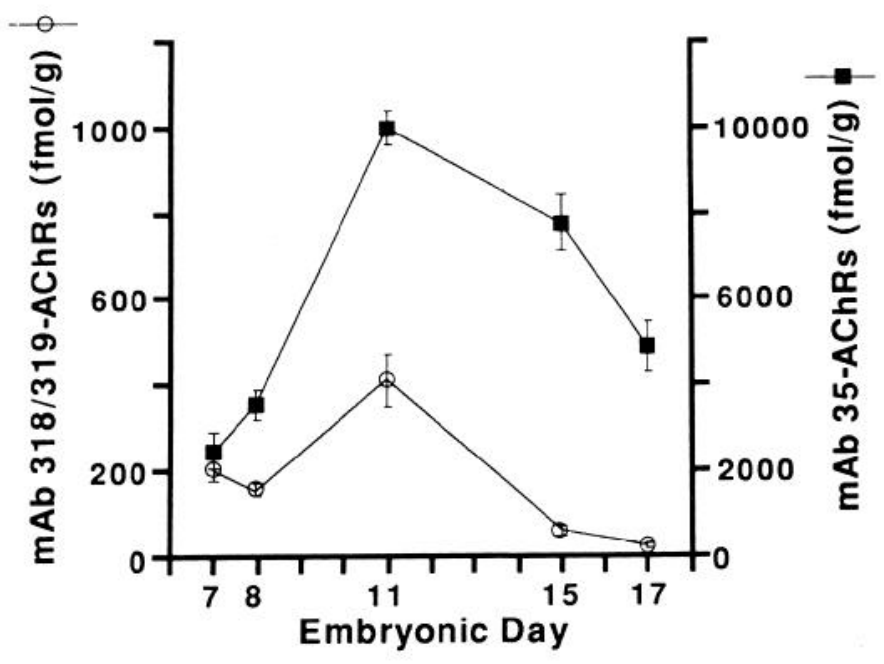

Figure 8. Putative AChRs containing $\alpha 7$ protein are expressed transiently in developing muscle. Solid phase assays with mAbs $318 / 319$ and 35 were used to quantify the numbers of $\alpha$ Bgt-binding sites associated with $\alpha 7$-containing components (open circles) and $\alpha 1$-containing AChRs (solid squares), respectively, in muscle extracts of the indicated developmental stages as described in Table 1. Each point represents the mean \pm SEM of at least eight determinations from three or more separate experiments. Though putative $\alpha 7$-containing receptors are less abundant than conventional $\alpha 1$-containing AChRs in muscle, the two types of receptors rise and fall together during development and parallel the levels of transcript present. cates the presence of $\alpha 7$ protein (Fig. 7). mAb 210, which recognizes the chicken muscle $\alpha 1$ protein on immunoblots (Conroy et al., 1992), failed to detect a component in the purified material, indicating that little, if any, $\alpha 1$ protein copurified with $\alpha 7$ (Fig. 7). Taken together, the results of both the immunoprecipitation and immunopurification experiments indicate that $\alpha 1$ and $\alpha 7$ subunits are segregated into separate multimeric species in embryonic muscle.

Subunit-specific mAbs were also used to determine whether the other neuronal AChR genes expressed in muscle contributed subunits that coassembled with either $\alpha 1$ or $\alpha 7$ subunits. These included $\mathrm{mAb} 289$, which recognizes the $\alpha 4$ gene product (Whiting et al., 1991); mAb B4-1, which recognizes the $\beta 4$ gene product (Vernallis et al., 1993); and mAb 268, which recognizes the $\alpha 5$ gene product (Conroy et al., 1992). Neither mAb 289 nor mAb B4-1 was able to immunoprecipitate muscle AChRs that bound ${ }^{125} \mathrm{I}-\alpha \mathrm{Bgt}$ or ${ }^{125} \mathrm{I}-\mathrm{mAb} 35$ (Table 1), though both antibodies recognize their respective antigens when present in receptors under such conditions. mAb 268, which recognizes its antigen only on immunoblots, failed to detect any $\alpha 5$ subunit in protein immunopurified with mAb 319-Protein G-Sepharose and subjected to immunoblot analysis (data not shown). Previous results showed that $\mathrm{mAb} 268$ does not react with components of muscle AChRs affinity-purified with $\alpha$ Bgt (Conroy et al., 1992). The results indicate that the $\alpha 4, \beta 4$, and $\alpha 5$ proteins are absent from muscle AChRs that bind $\alpha \mathrm{Bgt}$.

Developmental changes in muscle levels of $\alpha 7$ protein. Quantification of $\alpha 7$ proteins that bind $\alpha \mathrm{Bgt}$ in embryonic muscle 
demonstrated that the pattern of accumulation during development follows that of conventional $\alpha 1$-containing AChRs recognized by $\mathrm{mAb} 35$. Both the $\alpha 1$-containing $\mathrm{AChRs}$ and the putative AChRs containing $\alpha 7$ subunits are present at E7, peak at E11, and subsequently decrease in abundance (Fig. 8). The ratc of dccrease after E11 is greater, however, for putative $\alpha 7$ containing AChRs. They are $8 \%$ as abundant as the $\alpha 1$-containing receptors at $\mathrm{E} 7$ but less than $1 \%$ as abundant at E17. The results indicate that the putative $\alpha 7$-containing AChRs are present at early times in muscle development and that the amounts are roughly proportional to the amounts of $\alpha 7$ transcript present at each stage (Figs. $3 B, 8$ ).

\section{Discussion}

The major findings reported here are that embryonic skeletal muscle expresses several neuronal $\mathrm{AChR}$ genes. In the case of the $\alpha 7$ gene, the resulting transcripts are translated into protein that assembles into a multimeric species that binds $\alpha$ Bgt and has the size expected for an $\mathrm{AChR}$. The results reveal a pattern of expression for neuronal AChR genes more diverse than previously appreciated and raise questions regarding the function of neuronal AChRs in non-neuronal cells.

The stringency of the RNase protection assay leaves little doubt that the neuronal AChR gene transcripts were correctly identified. The amounts of neuronal AChR mRNAs are significant, in some cases approaching $20 \%$ of that observed for $\alpha 1$. The in situ hybridizations confirmed that the $\alpha 7$ gene is expressed in muscle cells both in cell culture where myotubes can be readily distinguished and in embryonic muscle where a variety of cell types and developmental stages coexist (Bourne, 1972)

The pattern of neuronal AChR gene expression in muscle appears unique. Of the four genes shown to be expressed in embryonic muscle, the transcript levels of two ( $\alpha 4$ and $\alpha 7)$ decline substantially between E11 and E17, as does the transcript level of $\alpha 1$, while the other two ( $\alpha 5$ and $\beta 4$ ) decrease only moderately. In contrast, transcript levels of all five neuronal $A C h R$ genes expressed in chick ciliary ganglia increase significantly per neuron during the same time period (Corriveau and Berg, 1993). No transcripts were detected in muscle from four other neuronal AChR genes $(\alpha 2, \alpha 3, \alpha 8$, and $\beta 3)$, and none of eight genes tested appeared to be expressed in E17 liver with the exception of $\alpha 5$ at very low levels. Of particular note is the absence of $\alpha 3$ transcripts in embryonic muscle though it appears in all classes of peripheral neurons tested to date including sympathetic, parasympathetic, and sensory neurons as well as adrenal chromaffin cells (Boulter et al., 1986; Boyd et al., 1991; Listerud et al., 1991; Corriveau and Berg, 1993). $\alpha 3$ transcripts are also absent from denervated muscle (Boulter et al,, 1986). Several human non-neuronal carcinoma cell lines (Chini et al., 1992) as well as thymic tissues (Mihovilovic and Roses, 1993) have been shown to express certain neuronal $A C h R$ genes, although it is not clear which neuronal AChR proteins might be present in the cells. It is possible that neuronal AChRs play a role very early in development, since the $\alpha 7$ promoter is active in cultures of undifferentiated mesoderm stem cells (Matter-Sadzinski et al., 1992). The diversity in neuronal AChR gene expression among cell types suggests specific regulation to produce needed receptor subtypes rather than a lack of precision in transcriptional control at early times.

The immunoprecipitation and immunoblot experiments demonstrate that $\alpha 7$ protein is present in embryonic muscle tissue. Furthermore, the developmental pattern of expression follows that of the $\alpha 7$ transcript with protein levels peaking at E11 and then falling substantially. Sucrose gradient analysis indicates that a large portion of the $\alpha 7$-containing protein is present in a species having the size expected for a fully assembled AChR. Though it has yet to be shown that the protein is present in the plasma membrane and functions as a receptor, such an outcome seems likely. Expression of the $\alpha 7$ gene alone in Xenopus oocytes produces functional AChRs that are thought to be homomeric (Couturier et al., 1990; Seguela et al., 1993). The same may be true of $\alpha 7$-containing AChRs in chick ciliary ganglion neurons, which are functional and contain only $\alpha 7$ of the known neuronal AChR gene products (Vernallis et al., 1993; Zhang et al., 1994). Alternatively, the $\alpha 7$ gene product may be coassembled with other AChR gene products normally expressed in muscle, including $\beta 1, \gamma$, and/or $\delta$. Recent evidence indicates that such AChR hybrids, when expressed in Xenopus oocytes, are functional (Helekar et al., 1994). The sequential immunoprecipitation studies with mAbs 35 and 318/319 show that the $\alpha 7$ subunits are not coassembled with $\alpha 1$ in muscle.

It seems unlikely that presynaptic neuronal AChRs, if such receptors exist on motor nerve terminals, could account for the bulk of the $\alpha 7$ protein detected in muscle. In situ hybridizations detected $\alpha 7$ transcript in muscle cells both in culture and in embryonic tissue with no indication of neurons being present. The levels of $\alpha 7$ protein in the muscle are proportional to the amounts of $\alpha 7$ mRNA at all times examined. In addition, the level of $\alpha 7$ protein in the tissue declines with development rather than increasing as might be cxpected if the protein were largely contributed by the innervating nerve. Preliminary studies on myotube cultures indicate that $\alpha 7$ protein is produced in the absence of neurons (S. J. Romano and D. K. Berg, unpublished observations). Nonetheless, the present results do not exclude the possibility that a portion of the $\alpha 7$ protein detected in embryonic muscle derives from motoneuron terminals.

Functional receptors containing $\alpha 7$ protein in muscle would have gone undetected in electrophysiological studies because the receptors would have been blocked by many of the same antagonists that block conventional muscle AChRs, namely, $\alpha \mathrm{Bgt}$, $\alpha$-cobrotoxin, and $d$-tubocurarine. The presence of $\alpha 4, \alpha 5$, and $\beta 4$ transcripts suggests that other types of neuronal AChRs may also be transiently expressed in developing muscle. The encoded subunits of the three genes would not be expected to produce receptors that bind $\alpha \mathrm{Bgt}$ or to coassemble with $\alpha 7$ subunits (Vernallis et al., 1993). As a result, receptors containing $\alpha 4, \alpha 5$, and $\beta 4$ subunits would not have been detected in the present studies. The expression of AChRs displaying a considerable range of single-channel properties in embryonic muscle has been interpreted as meaning that incomplete muscle AChR species can be assembled in the cells and transported to the cell surface (Liu and Brehm, 1993). An alternative possibility that should be considered in light of the present results is that a portion of the single-channel classes observed may represent neuronal AChRs transiently expressed in the cells.

Changes in the combination of ligand-gated ion channel genes expressed in a cell may be a general feature of development. The reasons for such changes, however, are poorly understood. In the case of muscle AChRs, it has been suggested that the expression of an embryonic form of the receptor having a $\gamma$ subunit may promote spontaneous receptor activity needed to establish neuromuscular junctions (Jaramillo et al., 1988). The early expression of ligand-gated ion channels has also led to 
speculation that the receptors help mediate other aspects of neuronal development, including the shaping of neuronal connectivity patterns (Bettler et al., 1990; Matter et al., 1990; Killisch et al., 1991). Supporting evidence in the case of NMDA receptors has been provided by the finding that receptor antagonists disrupt eye-specific stripes in the optic tectum of threeeyed tadpoles and pattern formation in the mammalian lateral geniculate nucleus (Cline et al., 1987; Hahm et al., 1991).

Identifying a role for $\alpha 7$-containing receptors in non-neuronal cells may suggest new functions for ligand-gated ion channels. An interesting possibility in developing muscle is that the receptors facilitate a specific step such as myoblast fusion or early events in synaptogenesis by virtue of their ability to elevate intracellular calcium levels. Expression of the $\alpha 7$ gene in Xenopus oocytes produces receptors with a calcium:sodium permeability much greater than that of conventional muscle AChRs (Bertrand et al., 1993; Seguela et al., 1993). As a result, even a few $\alpha 7$-containing receptors might have profound effects on intracellular calcium levels at early times. Specific blockers of $\alpha 7$-containing AChRs should help reveal the possible roles of such receptors in muscle development.

\section{References}

Anand R, Peng X, Lindstrom J (1993) Homomeric and native $\alpha 7$ acetylcholine receptors exhibit remarkably similar but non-identical pharmacological properties, suggesting that the native receptor is a heteromeric protein complex. FEBS 327:241-246.

Bertrand D, Galzi JL, Devillers-Thiery A, Bertrand S, Changeux JP (1993) Mutations at two distinct sites within the channel domain M2 alter calcium permeability of neuronal $\alpha 7$ nicotinic receptor. Proc Natl Acad Sci USA 90:6971-6975.

Bettler B, Boulter J, Hermans-Borgmeyer I, O'Shea-Greenfield A, Deneris ES, Moll C, Borgmeyer U, Hollmann M, Heinemann S (1990) Cloning of a novel glutamate receptor subunit, GluR5: expression in the nervous system during development. Neuron 5:583-595.

Boulter J, Evans K, Goldman D, Martin G, Treco D, Heinemann S, Patrick J (1986) Isolation of a cDNA clone coding for a possible neural nicotinic acetylcholine receptor $\alpha$-subunit. Nature 319:368374.

Bourne GH (1972) The structure and function of muscle, Vol I. New York: Academic.

Boyd RT, Jacob MH, McEachern AE, Caron S, Berg DK (1991) Nicotinic acetylcholine receptor mRNA in dorsal root ganglion neurons. J Neurobiol 22:1-14.

Chini B, Clementi F, Hukovic N, Sher E (1992) Neuronal-type $\alpha$-bungarotoxin receptors and the $\alpha 5$-nicotinic receptor subunit gene are expressed in neuronal and nonneuronal human cell lines. Proc Nat Acad Sci USA 89:1572-1576.

Chomczynski P, Sacchi N (1987) Single-step method of RNA isolation by acid guanidinium thiocyanate-phenol-chloroform extraction. Anal Biochem 162:156-159.

Cline HT, Debski EA, Constantine-Paton M (1987) N-methyl-D-aspartate receptor antagonist desegregates eye-specific stripes. Proc Natl Acad Sci USA 84:4342-4343.

Conroy WG, Vernallis AB, Berg DK (1992) The $\alpha 5$ gene product assembles with multiple acetylcholine receptor subunits to form distinctive receptor subtypes in brain. Neuron 9:679-691.

Corriveau RA, Berg DK (1993) Coexpression of multiple acetylcholine receptor genes in neurons: quantification of transcripts during development. J Neurosci 13:2662-2671.

Couturicr S, Bcrtrand D, Matter J-M, Hernandez M-C, Bertrand S, Millar N, Valera S, Barkas T, Ballivet M (1990) A neuronal nicotinic acetylcholine receptor subunit $(\alpha 7)$ is developmentally regulated and forms a homo-oligomeric channel blocked by $\alpha$-BTX. Neuron 5:847856.

Fischbach GD (1972) Synapse formation between dissociated nerve and muscle cells in low density cell cultures. Dev Biol 28:407-429.

Fontaine B, Changeux J-P (1989) Localization of nicotinic acetylcholine receptor $\alpha$-subunit transcripts during myogenesis and motor endplate development in the chick. J Cell Biol 108:1025-1037.
Hahm JO, Langdon RB, Sur M (1991) Disruption of retinogeniculate afferent segregation by antagonists to NMDA receptors. Nature 351: $568-570$.

Hall ZW, Sanes JR (1993) Synaptic structure and development: the neuromuscular junction. Cell/Neuron [Suppl] 72/10:99-121.

Harlow E, Lane D (1988) Antibodies. A laboratory manual. Cold Spring Harbor, New York: Cold Spring Harbor Laboratory.

Helekar SA, Char D, Neff S, Patrick J (1994) Prolyl isomerase requirement for the expression of functional homo-oligomeric ligandgated ion channels. Neuron 12:179-189.

Humason GL (1979) Animal tissue techniques. San Francisco: Freeman.

Jaramillo F, Vicini S, Schuetze SM (1988) Embryonic acetylcholine receptors guarantee spontaneous contractions in rat developing muscle. Nature 335:66-68.

Killisch I, Dotti CG, Laurie DJ, Luddens H, Seeburg PH (1991) Expression patterns of $\mathrm{GABA}_{\mathrm{A}}$ receptor subtypes in developing hippocampal neurons. Neuron 7:927-936.

Listerud M, Brussaard AB, Devay P, Colman DR, Role LW (1991) Functional contribution of neuronal AChR subunits revealed by antisense oligonucleotides. Science 254:1518-1521.

Liu Y, Brehm P (1993) Expression of subunit-omitted mouse nicotinic acetylcholine receptors in Xenopus laevis oocytes. J Physiol (Lond) 470:349-363

Matter J-M, Matter-Sadzinski L, Ballivet M (1990) Expression of neuronal nicotinic acetylcholine receptor genes in the developing chick visual system. EMBO J 9:1021-1026.

Matter-Sadzinski L, Hernandez M-C, Rotzocil T, Ballivet M, Matter J-M (1992) Neuronal specificity of the $\alpha 7$ nicotinic acetylcholine receptor promoter develops during morphogenesis of the central nervous system. EMBO J 1 1:4529-4538.

McLane KE, Wu X, Lindstrom JM, Conti-Tronconi BM (1992) Epitope mapping of polyclonal and monoclonal antibodies against two $\alpha$-bungarotoxin-binding $\alpha$ subunits from neuronal nicotinic receptors. J Neuroimmunol 38:115-128.

Mihovilovic M, Roses AD (1993) Expression of $\alpha 3, \alpha 5$, and $\beta 4$ neuronal acetylcholine receptor subunit transcripts in normal and myasthenia gravis thymus. Identification of thymocytes expressing the $\alpha 3$ transcripts. J Immunol 151:6517-6524.

Moss SJ, Darlison MG, Beeson DMW, Barnard EA (1989) Developmental expression of the genes encoding the four subunits of the chicken muscle acetylcholine receptor. J Biol Chem 264:20199-20205.

Nishi R, Berg DK (1981) Two components from eye tissue that differentially stimulate the growth and development of ciliary ganglion neurons in cell culture. J Neurosci 1:505-513.

Przybylski RJ, Blumberg JM (1966) Ultrastructural aspects of myogenesis in the chick. Lab Invest 15:836-863.

Ravdin PM, Berg DK (1979) Inhibition of neuronal acetylcholine sensitivity by $\alpha$-toxins from Bungarus multicinctus venom. Proc Natl Acad Sci USA 76:2072-2076.

Sargent PB (1993) The diversity of neuronal nicotinic acetylcholine receptors. Annu Rev Neurosci 16:403-443.

Schneider M, Adee C, Betz H, Schmidt J (1985) Biochemical characterization of two nicotinic receptors from the optic lobe of the chick. J Biol Chem 260:14505-14512.

Schoepfer R, Conroy WG, Whiting P, Gore M, Lindstrom J (1990) Brain $\alpha$-bungarotoxin binding protein cDNAs and MAbs reveal subtypes of this branch of the ligand-gated ion channel gene superfamily. Neuron 5:35-48.

Seguela P, Wadiche J, Dineley-Miller K, Dani JA, Patrick JW (1993) Molecular cloning, functional properties, and distribution of rat brain $\alpha 7$ : a nicotinic cation channel highly permeable to calcium. J Neurosci 13:596-604.

Shieh BH, Ballivet M, Schmidt J (1987) Quantitation of an alpha subunit splicing intermediate: evidence for transcriptional activation in the control of acetylcholine receptor expression in denervated chick skeletal muscle. J Cell Biol 104:1337-1341.

Simmons DM, Arriza JL, Swanson LW (1989) A complete protocol for in situ hybridization of messenger RNAs in brain and other tissues with radiolabeled single-stranded RNA probes. J Histotechnol 12: 169-181.

Smith MA, Stollberg J, Lindstrom JM, Berg DK (1985) Characterization of a component in chick ciliary ganglia that cross reacts with monoclonal antibodies to muscle and electric organ acetylcholine receptor. J Neurosci 5:2726-2731. 
Sucher NJ, Brose N, Deitcher DL, Awobuluyi M, Gasic GP, Bading H, Cepko CL, Greenberg ME, Jahn R, Heinemann SF, Lipton SA (1993) Expression of endogenous NMDAR1 transcripts without receptor protein suggests post-transcriptional control in PC12 cells. J Biol Chem 268:22299-22304.

Towbin H, Staehelin T, Gordon J (1979) Electrophoretic transfer of proteins from polyacrylamide gels to nitrocellulose sheets: procedure and some applications. Proc Natl Acad Sci USA 76:4350-4354.

Vernallis AB, Conroy WG, Berg DK (1993) Neurons assemble ace- tylcholine receptors with as many as three kinds of subunits while maintaining subunits segregation among receptor subtypes. Neuron $10: 451-464$

Whiting PJ, Schoepfer R, Conroy WG, Gore MJ, Keyser KT, Shimasaki S, Esch F, Lindstrom JM (1991) Expression of nicotinic acetylcholine receptor subtypes in brain and retina. Mol Brain Res 10:61-70. Zhang Z-w, Vijayaraghavan S, Berg DK (1994) Neuronal acetylcholine receptors that bind $\alpha$-bungarotoxin with high affinity function as ligand-gated ion channels. Neuron 12:167-177. 